Research article

\title{
Whats drive someone to share their knowledge? Indonesia virtual community case
}

\author{
Deki Satria \\ email:deki.satria@bri-institute.ac.id

\begin{tabular}{l}
\hline A R T I C L E I N F O \\
\hline Article history: \\
Received 14 October 2020 \\
Revised 1 February 2021 \\
Accepted 5 March 2021 \\
Available online 4 May 2021 \\
\hline Keywords: \\
community of practices \\
knowledge management \\
knowledge sharing \\
SEM-PLS \\
virtual community \\
\hline Please cite this article in IEEE style \\
as: \\
D. Satria, " Whats drive someone to \\
share their knowledge? Indonesia \\
virtual community case," Register: \\
Jurnal Ilmiah Teknologi Sistem Informasi, \\
vol. 7, no. 2, pp. 164-172, 2021.
\end{tabular}

Institut Teknologi dan Bisnis Bank Rakyat Indonesia, Jakarta, Indonesia

\section{A B S T R A C T}

A virtual community is one form of Community of Practices that resides on the internet. This community consists of people who share problems or interests in specific topics. A lot of knowledge comes from this kind of community where the members shared their knowledge voluntarily. Knowledge itself is a valuable resource that gives the owner have an advantage. This research tried to observe what are the driver of this behavior. Knowing these variables could help the organization in defining knowledge sharing system functionality. The variables collected using PRISMA Systematic Literature Review (SLR) protocols, and the hypotheses tested using Partial Least Squares Structural Equation Modeling (PLS-SEM). From this research, we observed that self-efficacy and supporting others significantly influence someone to share their knowledge.

Register with CC BY NC SA license. Copyright $\odot$ 2021, the author(s)

\section{Introduction}

Pandemic changes the way we work. A lot of work shifted into digital environments, like sharing documents, conducting online meetings, and online classes. All of this shifting work environment made the bloom of Digital Community of practices, including in the Academic world. Many community-made webinars to teach or share knowledge in the specific area that the community specialized.

In this case, the community of practices is defined as a Community. The members have some value, interest, or admiration in specific topics and want to deepen their knowledge or gain experience about such topics via discussion [1]. On the other hand, a virtual community can be defined as a community that resides on the internet [2,3]. Furthermore, Wang et al., [4] described that in the information system, there were two kinds of virtual communities, which are collaborative Community and Community, to share knowledge.

Virtual communities are usually formed by peoples who have a common interest in some topics or issues. The members can be anywhere around the globe, which made the knowledge pooled was big and diverse. The growth of the virtual community of practices was observed to be significant. In 2019 global web index found that $79 \%$ internet users uses the internet to access virtual community [5]. This growth shows that in the future, more knowledge will be shared in the community.

Knowledge is an asset for the entity that has it [6]. This knowledge gave the organization or the person who owned it has a competitive advantage. Therefore, the entity who had it has tendencies to keep their knowledge a secret.

Anomaly happens in the virtual community. Even though still considered an asset, the members share it with other people even though the one who shares their knowledge did not personally know the people who receive the ability. 
This paper tried to investigate why did the members share their knowledge in the virtual community. Factors to be observed already found in our previous study [7]. This paper attempted to see these factors through a virtual Community established in Indonesia, and the community members are Indonesian. Knowing the driver of sharing in the community could significantly increase the knowledge sharing system's success in an organization or community. An example of this sharing system is the virtual community of practices. Suppose an organization creates some virtual community of practices system to share knowledge in the community. In that case, the organization could implement functionality that enhances the community members' willingness to share their knowledge.

\section{Research Methodology}

The step of this research can be seen in Fig. 1. We will elaborate on each step in the sub-chapters.

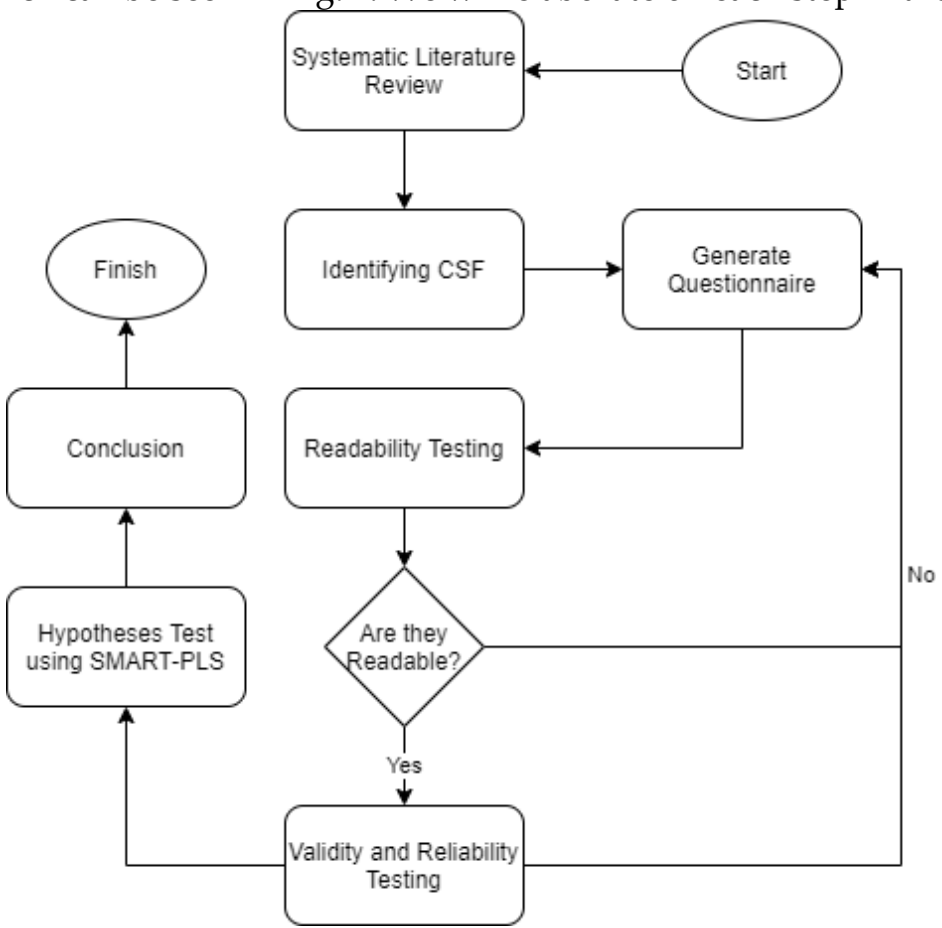

Fig. 1. Research step

1. Systematic Literature Review (SLR)

This research starts with a systematic literature review (SLR). In this research, we used the PRISMA framework to collect and summarize the finding. Fig. 2 represents the step of PRISMA Methodology. The first step of this framework is composing-the paper through a research database. In this research, we used IEEEXplore, Sciencedirect, and Proquest. After collecting the articles and review the papers, we summarize the finding and develop the research model from this review. The summary of finding from any publication that contains the Critical Success Factors of sharing in the Virtual Community [7].

2. Critical Success Factor (CSF)

Organizations could use critical success factors (CSF) to improve their organization [8]. CSF became important when an organization wants to improve its ability and capability. These CSF usually achieved through systematic literature review. In this study, we used CSF to see the driver of sharing in the virtual community. CSF in Sharing:

- Support Other

Supporting others or Altruism Behavior is defined as a selfless act that shows someone eagerness to help others [9]. This altruistic behavior mentioned in numerous paper which discussed the virtual community. These papers said that people want to help others in their community [10], Yan et al., [11], and Chen et al., [12].

- Sense of Community Another factor which we got is the Sense of Community. Sense of community defined as the feeling of belonging of the community member and they are matter among their community or group [13]. The sense of community also became factors that drive someone to share their knowledge in their community $[14,15,16]$. 
- Gain Benefit One of the reasons someone shares their knowledge was to gain benefits, also mentioned in some papers. This benefit, such as reputation [11] and recognition [15, 17], became one reasons people share their knowledge in the virtual community.

- Self-Efficacy Self-efficacy mentioned in several papers [14, 18]. Self-efficacy itself can be described as an act when someone feels they had the capability in certain aspects [19]. This act of self-efficacy can drive someone to share their knowledge because they know that what they give to the community is the thing they know.

- Discuss Specifics Problems Sometimes, someone shares what they know to discuss that knowledge. These papers $[20,21]$ mentioned the driver of sharing. The topics that people discuss can be specific issues or when the poster needs improvements in their knowledge. Alali et al., [22] in their paper, describe that the virtual community consists of people who had the same interest and want to share what they experience on the topics. This driver is mentioned in Yan et al., [11], Wang et al., [20], Alali et al., [22], and Abdullah et al., [23].

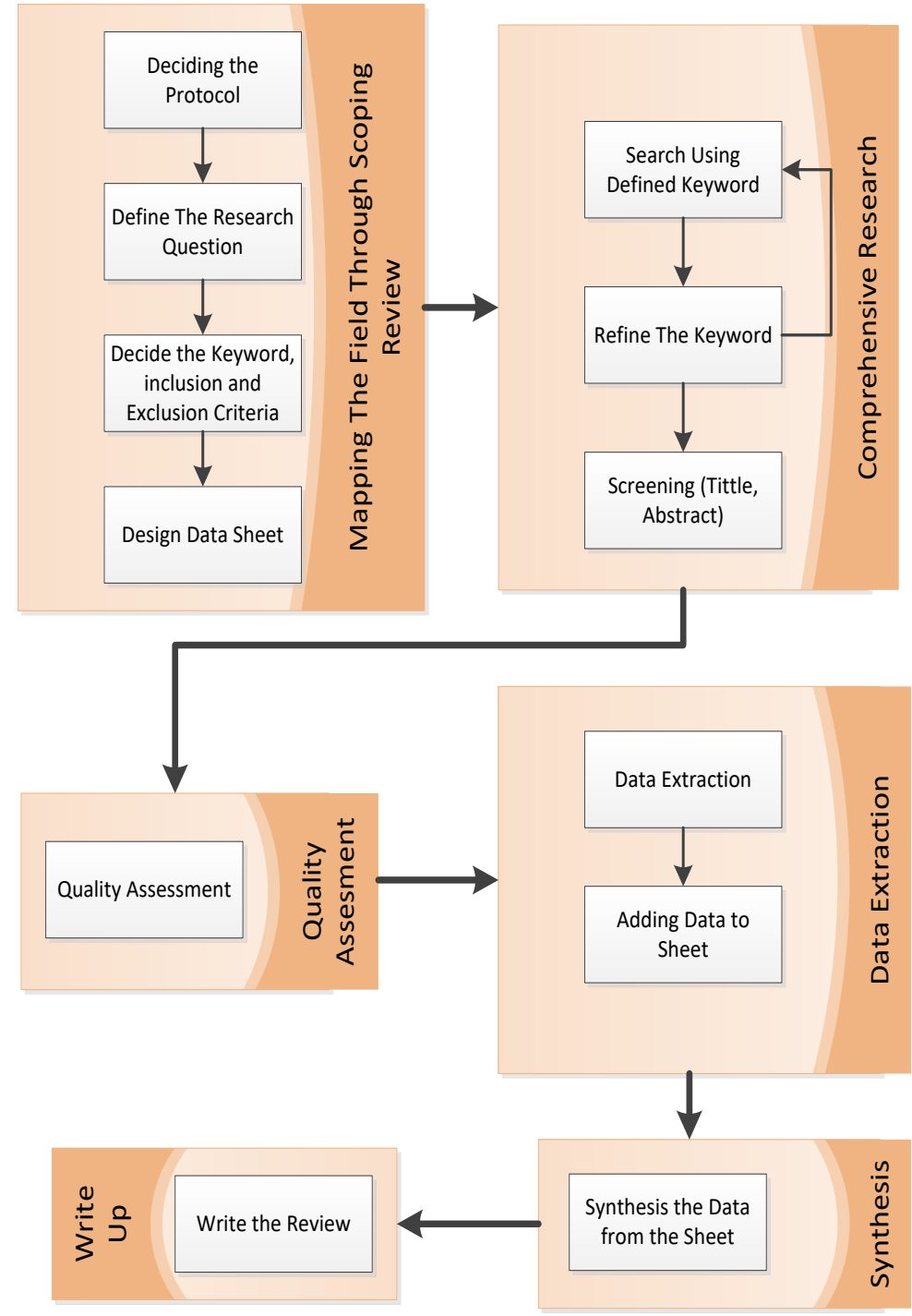

Fig. 2. PRISMA framework [7]

3. Generate questionnaire

4. Validity and reliability

5. Hypothesis test using SEM-PLS

6. Conclusion

\section{Research Model and Hypotheses Testing}

This research is exploratory research conducted to observe the community members' behavior in Virtual Community. In this research, we used PLS-SEM to test the hypotheses. The model used in this research can be seen in Fig. 3. 


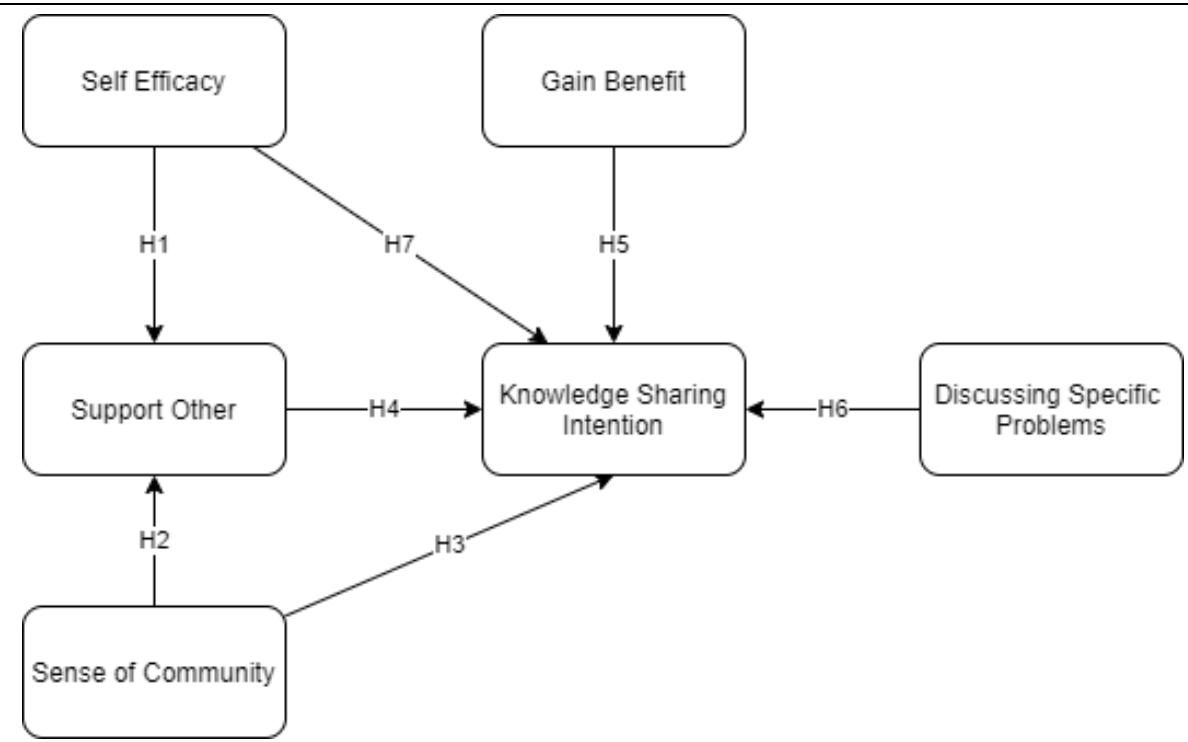

Fig. 3. Research model

The hypotheses of this research were:

H1: Self Efficacy have a positive impact on support others Someone with self-efficacy usually has the will to help others. In this hypothesis, we tried to see if the Virtual Community members have this will to support others when they knew about the discussed problems.

H2: Sense of Community have a Positive Impact on Support Others We predicted that when someone has a sense of belonging in their community, they will help the other members even though they don't have the expertise in the discussed problems. They support others in these factors, not only in the form of knowledge but also in other forms such as recommendation, link, etc.

H3: Sense of Community have a positive impact on Knowledge Sharing Behavior We predicted that when someone knew how to solve the discussed problems, they would help solve said problems. Oppositely, someone who knew how to solve problems but has no sense of community will hide their knowledge and not help solve said problems. This CSF proved to be true in the voluntary community mentioned in kaewkitipong research [10]. This research shows how voluntary communities help their community solve the problems they met in a natural disaster.

H4: Support others have a positive impact on knowledge sharing intention. Will to help others have a positive impact on others' will to share their knowledge. Yilmaz [14], Changping et al., [15], and Usoro et al., [16] observed this factor in their respective research. Therefore, in this research, we want to prove if this factor is one factor that made someone share their knowledge in their community.

H5: Gain Benefit have a positive impact on Knowledge Sharing Intention This factor is one of the most mentioned factors when people discuss sharing intention. In our systematic literature review, we found that these researchers $[11,15,17]$ has mentioned this factor in their respective research. The benefit of sharing could be in the form of recognition, reputation, or another form of benefit, such as financial benefit, even though the sharer will not get it directly. The sharer can achieve financial gain when they get a reputation, and other community members give them a project. This project can usually be found in the Technical Community of Practices.

H6: Discussing Specific Problems positively impact Knowledge Sharing Intention Wang et al., [20], and Guimaraes [21] mentioned that Virtual communities formed to discuss specific problems. For example, StackOverflow formed to discuss issues in the programming area. Therefore discussing something could also become factors why people share their knowledge. This sharing may be because they want some innovation about the knowledge they have or enhance their knowledge.

H7: Self Efficacy have a positive impact on Knowledge Sharing Intention Someone who knows they have the expertise in specific topics tends to share what they know to her/his community. Yan et al., [11], Wang et al., [20], Alali et al., [22], and Abdullah et al., [23] mentioned this factor in their research. In this research, we want to observe is the factor applied to the virtual community.

\section{Results and Discussion}




\subsection{Results}

In this research, we spread the questionnaire into several Virtual Communities. We use Google Form as the questionnaire tool. We gather 135 data from this step, but only 120 data are eligible for use because some data have missing data or are filled incorrectly.

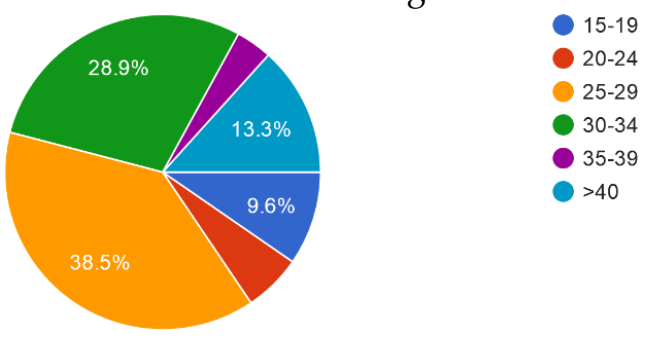

(a)

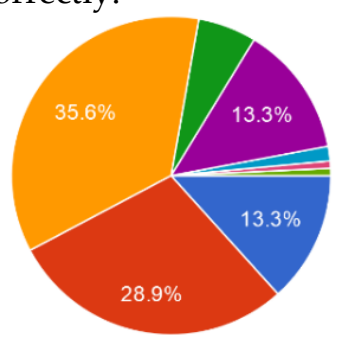

(b)

Fig. 4. (a) Respondents age; (b) Respondents education

As shown in Fig. 4, the respondence of this questionnaire's response mainly ranged from 25 to 29. The respondent's education level entirely differed, ranging from SMA (Highschool Students) to the Doctoral Level. From this graph, we know that the observed COP has quite diverse members, and the knowledge gathered from the COP could be an asset for the community. This knowledge became an asset because the more experienced members could give the community their experience and expertise, and the less experience could trigger the discussion through their problems. From this graph, we also know age does not become a barrier to sharing in COP.

\begin{tabular}{|c|c|c|c|c|c|c|}
\hline & $\begin{array}{c}\text { Discuss Specific } \\
\text { Problem }\end{array}$ & $\begin{array}{c}\text { Gain } \\
\text { Benefit }\end{array}$ & $\begin{array}{c}\text { Knowledge Sharing } \\
\text { Intention }\end{array}$ & $\begin{array}{c}\text { Self } \\
\text { Efficacy }\end{array}$ & $\begin{array}{c}\text { Sense of } \\
\text { Community }\end{array}$ & $\begin{array}{c}\text { Support } \\
\text { Other }\end{array}$ \\
\hline DISC1 & 0.9003 & & & & & \\
\hline DISC2 & 0.8947 & & & & & \\
\hline DISC3 & 0.9444 & & & & & \\
\hline DISC4 & 0.9070 & & & & & \\
\hline GB1 & & 0.8148 & & & & \\
\hline GB2 & & 0.8171 & & & & \\
\hline GB3 & & 0.8619 & & & & \\
\hline SBO1 & & & & & 0.7785 & \\
\hline SBO2 & & & & & 0.7900 & \\
\hline SBO3 & & & & & $0.6350^{*}$ & \\
\hline SBO4 & & & & & $0.6544^{*}$ & \\
\hline SE1 & & & & 0.9178 & & \\
\hline SE2 & & & & 0.9144 & & \\
\hline SE3 & & & & 0.8114 & & \\
\hline SE4 & & & & $0.6370^{*}$ & & \\
\hline SKI1 & & & 0.8649 & & & \\
\hline SKI2 & & & 0.8578 & & & \\
\hline SKI3 & & & 0.8632 & & & \\
\hline SO1 & & & & & & $0.4159^{*}$ \\
\hline $\mathrm{SO} 3$ & & & & & & $0.3426^{*}$ \\
\hline $\mathrm{SO} 4$ & & & & & & 0.8148 \\
\hline SO5 & & & & & & 0.7521 \\
\hline SO6 & & & & & & $-0.3208^{*}$ \\
\hline
\end{tabular}

The first step of this research is calculating the questionnaire items' outer loading, reliability, and validity. We used 0.7 as the outer loading threshold in this research - this threshold is perceived as satisfying or good when calculating Outer loading [24]. Outer loading is used to observe if the item in the questionnaire represents the observed variable. Outer loading calculated using single regression for each item/indicator to its construct [25] The result of the Outer loading calculation can be seen in Table 
1. Outer loading. The analysis in Table 1 shows that several items got values under 0.7 (SO1, SO3, SO6, SBO03, SBO4, and SE4) this result automatically provided by SMART-PLS. Therefore these items are deleted from the following calculation.

After calculating the Outer Loading, we calculate the Reliability and Validity of the questionnaire items. Reliability and Validity of the calculated items using AVE (Average Variant Extracted) and Construct Reliability (CR). In their book, Hair et al., [26] explain that CR is more reliable than Cronbach Alpha to calculate the reliability of the calculated item.

The composite reliability equation can be seen in Eq. 1 [27, 28].

$C R=\frac{\left(\sum \lambda_{i}\right)^{2}}{\left(\sum \lambda_{i}\right)^{2}+\left(\sum \epsilon_{i}\right)}$

where $\boldsymbol{\lambda}$ is standardized loading from item, $i$ and $\boldsymbol{\epsilon}$ is error variance estimated from the loading. The equation used to calculate the error is shown in Eq. $2[27,28]$.

$\epsilon_{i}=1-\lambda_{i}^{2}$

Eq. 3 AVE Equation shows the equation of AVE [29].

$A V E=\frac{\sum \lambda_{i}^{2}}{\sum \lambda_{i}^{2} \sum_{i} \operatorname{var}\left(\varepsilon_{i}\right)}$

where $\lambda_{i}$ is the loading factor value of the variable and $\operatorname{var}\left(\varepsilon_{i}\right)$ is the $1-\lambda_{i}$.

Table 2. Reliability and validity

\begin{tabular}{lcc}
\hline & Composite Reliability & Average Variance Extracted (AVE) \\
\hline Discuss Specific Problem & 0.9517 & 0.8314 \\
Gain Benefit & 0.8704 & 0.6915 \\
Knowledge Sharing Intention & 0.8966 & 0.7429 \\
Self Efficacy & 0.9206 & 0.7953 \\
Sense of Community & 0.8257 & 0.7033 \\
Support Other & 0.7902 & 0.6556 \\
\hline
\end{tabular}

Table 3. Hypotheses testing

\begin{tabular}{|c|c|c|c|c|c|}
\hline & $\begin{array}{c}\text { Original } \\
\text { Sample (O) }\end{array}$ & $\begin{array}{c}\text { Sample } \\
\text { Mean (M) }\end{array}$ & $\begin{array}{l}\text { Standard } \\
\text { Deviation } \\
\text { (STDEV) }\end{array}$ & $\begin{array}{l}\text { T Statistics } \\
(|\mathrm{O} / \mathrm{STDEV}|)\end{array}$ & P Values \\
\hline $\begin{array}{l}\text { Discuss Specific Problem -> } \\
\text { Knowledge Sharing Intention }\end{array}$ & 0.1731 & 0.1541 & 0.1070 & 1.6178 & 0.0530 \\
\hline $\begin{array}{l}\text { Gain Benefit -> Knowledge Sharing } \\
\text { Intention }\end{array}$ & -0.0154 & -0.0291 & 0.0714 & 0.2154 & 0.4147 \\
\hline $\begin{array}{l}\text { Self Efficacy -> Knowledge Sharing } \\
\text { Intention }\end{array}$ & 0.2987 & 0.3001 & 0.0952 & $3.1375^{*}$ & 0.0009 \\
\hline Self Efficacy -> Support Other & 0.5034 & 0.5033 & 0.0843 & $5.9735^{*}$ & 0.0000 \\
\hline $\begin{array}{l}\text { Sense of Community -> Knowledge } \\
\text { Sharing Intention }\end{array}$ & -0.1381 & -0.1199 & 0.0776 & $1.7808^{* *}$ & 0.0376 \\
\hline Sense of Community $->$ Support Other & 0.3232 & 0.3270 & 0.0830 & $3.8948^{*}$ & 0.0001 \\
\hline $\begin{array}{l}\text { Support Other -> Knowledge Sharing } \\
\text { Intention }\end{array}$ & 0.4491 & 0.4532 & 0.1039 & $4.3236^{*}$ & 0.0000 \\
\hline
\end{tabular}

In this research, we use CR to calculate the questionnaire item's reliability and AVE to calculate the questionnaire item's validity as defined by Hair et al., which are 0.7 for CR and 0.5 for AVE, indicating it is reliable and valid enough. Reliability itself is used to check if the questionnaire's item is reliable, which means if the same respondent fills the questionnaire the second time she/he, we will get the same result. Validity represents the questionnaire's understanding so that the response can fill the item accurately [30]. The result of Reliability and Validity testing can be seen in Table 2 Reliability and Validity.

As shown in Table 2, all the observed variables exceed the threshold we defined. Therefore all the variable was valid and reliable. The last step of the research is to calculate the hypotheses. In this research, we use T-Statistic to calculate the Hypotheses. Eq. 4 T-Statistic Equation shows the T-Statistic equation [31]. The result of the hypotheses testing can be seen in Table 3. 
where $t$ is the $t$ value $x_{1}$ and $x_{2}$ are the means of the group being compared. $S^{2}$ represents the pooled standard error of the two groups being compared. $n$ is the number of observations of each corresponding group.

Table 3 shows that four hypotheses are accepted on a p-value of 0.01 , which is highly significant. One hypothesis is accepted on p-Value 0.05 , which is moderately significant. Two hypotheses were rejected even when we used p-Value 0.1 , where 0.1 means a low significance level.

\subsection{Discussion}

From the result section, we can see that four hypotheses are accepted with high significance, and one hypothesis accepted with moderate significance. This section will discuss why the hypotheses are accepted and why some of the hypotheses are rejected.

Self-efficacy became the most significant factor in driving someone to share their knowledge. This factor also becomes an indirect factor for supporting others, which means someone will help others when they know they can help them solve their problems ( $p$-Value $=0.01, t-V a l u e=5.97)$. This result consistent with the results of other research. Someone with high self-efficacy has a higher probability of helping others than people with low self-efficacy [32]. In their book, Bandura also describes that selfefficacy significantly impacts someone's will to help others [19]We know that someone will help others even though they do not have any sense of community from this hypothesis. Another finding from this factor is that someone with self-efficacy will share their knowledge about the specific problems being discussed in the virtual community ( $\mathrm{p}$-value $=0.01$, $\mathrm{t}$-value $=3.13$ ). The difference between these two is that when someone has self-efficacy, not clear about the problems, they will try to help others. For example, when she/he does not know how to solve the issues but knows that he/she has the resource to that knowledge (library, book, helping in the search), they will help the community members.

As an organization, we could use this self-efficacy to strengthen the members' engagement by adding members' knowledge to the member's badge (beginner to master). This badge is also used in the Stackoverflow to add a sense of efficacy to the members. This badge will level up if the members contribute to the community.

The following hypothesis with significant results is a sense of community to support others. When someone has a sense of belonging in their community, they will help their community members ( $p$-value $=0.01, t$-value $=3.8$ ). This factor has some connection with the rejected hypothesis: Gain Benefit has a positive impact on Knowledge Sharing Intention (H5). This result stems from Indonesian culture Gotong Royong. We can define Gotong Royong as mutual assistance between the group in Indonesia's community or cooperative behavior [33]. This behavior happens because of reciprocation behavior in the community. When someone gets help from others, this will make them feel like a part of the community, enhancing their sense of community. Therefore, developing gamification in the virtual community will not help in strengthening the engagement of the members.

Sense of community and Knowledge sharing intention (H3) have moderate significance. As mentioned before, that sense of community has more impact on someone's will to support others. Therefore we can say Sense of Community, not a direct factor, instead work as an indirect factor that influences someone to share their knowledge.

Another rejected hypothesis is to Discuss specific problems that positively impact someone's willingness to share their knowledge. This hypothesis was rejected because, if we see the content or question in the VCOP, we rarely see someone share what they know; instead, they share what they don't know or problems in a particular area. Therefore, they do not have any reason to share.

\section{Conclusion}

From this research, we know that some variables influence someone's willingness to share their knowledge in a virtual community of practice. These variables are a sense of community, will to help others, and self-efficacy. An organization can use this result when developing a virtual community in their organization, for example, a school to help discussion flow in their virtual class. In the virtual class, we know that sometimes the discussion board does not have any responses even though we include 

Therefore, developing the gamification functionality will not enhance the students' engagement. Still, we know that if the students have a sense of community or, in this case, a sense of belonging in the class, they will gladly engage in the topics or questions. Adding the knowledge level badge could also strengthen the member's self-confidence about their knowledge.

\section{Declaration of Competing Interest}

We declare that we have no conflict of interests.

\section{References}

[1] J. B. d. Silva, S. M. S. Bilessimo and I. N. d. Silva, "Collaborative virtual community to share class plans for STEAM education," in 2020 IEEE Global Engineering Education Conference (EDUCON), Porto, Portugal, 2020.

[2] H. Rheingold, The Virtual Community: Homesteading On The Electronic Frontier The Edge, The MIT Press, 2000.

[3] P. Kollock and M. Smith, Communities in Cyberspace, New York: Routledge, 1999.

[4] T. Wang, G. Yin, H. Wang, C. Yang and P. Zou, "Automatic Knowledge Sharing Across Communities: A Case Study on Android Issue Tracker and Stack Overflow," in 2015 IEEE Symposium on Service-Oriented System Engineering, San Francisco, CA, USA, 2015.

[5] C. Beer, "Chart of the Week The Rise of Online Communities," Global Web Index, 2020. [Online]. Available: https://blog.globalwebindex.com/chart-of-the-week/online-communities/.

[6] G. S. Erickson and H. N. Rothberg, "Knowledge assets in services across industries and across time," Investigaciones Europeas de Dirección y Economía de la Empresa, vol. 21, no. 2, pp. 58-64, 2015.

[7] D. Satria and S. A. Hendrawan, "Knowledge Sharing Driver in Virtual Community : A Systematic Review," BRITech (Jurnal Ilmiah Ilmu Komputer, Sains dan Teknologi Terapan), vol. 1, no. 1, pp. 7-15, 2019.

[8] Z. A. Al-Sai, R. Abdullah, M. H. Husin and S. M. Syed-Mohamad, "A Preliminary Systematic Performance on Critical Success Factors Categories for Big Data Analytics," International Journal of Engineering and Advanced Technology (IJEAT), vol. 9, no. 1, pp. 2320-2324, 2019.

[9] R. Neugebauer, P. Wickramaratne, C. Svob, C. H. McClintock, M. J. Gameroff, L. Miller and A. Conway, "Contribution of religion/spirituality and major depressive disorder to altruism," Journal of Affective Disorders, vol. 262, pp. 16-22, 2020.

[10] L. Kaewkitipong, C. C. Chen and P. Ractham, "A community-based approach to sharing knowledge before, during, and after crisis events: A case study from Thailand," Computers in Human Behavior, vol. 54, pp. 653-666, 2016.

[11] Z. Yan, T. Wang, Y. Chen and H. Zhang, "Knowledge sharing in online health communities: A social exchange theory perspective," Information E Management, vol. 53, no. 5, pp. 643-653, 2016.

[12] H.-L. Chen, H.-L. Fan and C.-C. Tsai, "The Role of Community Trust and Altruism in Knowledge Sharing: An Investigation of a Virtual Community of Teacher Professionals," Educational Technology \& Society, vol. 17, no. 3, p. 168-179, 2014.

[13] D. W. McMillan and D. M. Chavis, "Sense of Community: A Definition and Theory," Journal of Community Psychology, vol. 14, pp. 6-23, 1986.

[14] R. Yilmaz, "Knowledge sharing behaviors in e-learning community: Exploring the role of academic self-efficacy and sense of community," Computers in Human Behavior, vol. 63, pp. 373-382, 2016.

[15] H. Changping and W. Li, "The Influencing Factors of Knowledge Sharing Behavior on College Students in Virtual Communities," in 2014 13th International Symposium on Distributed Computing and Applications to Business, Engineering and Science, Xi'an, China, 2014.

[16] A. Usoro, M. W. Sharratt, E. Tsui and S. Shekhar, "Trust as an antecedent to knowledge sharing in virtual communities of practice," Knowledge Management Research \& Practice, p. 1-14, 2007. 
[17] T. Jadin, T. Gnambs and B. Batinic, "Personality traits and knowledge sharing in online communities," Computers in Human Behavior, vol. 29, no. 1, pp. 210-216, 2013.

[18] D. Yuan, Z. Lin and R. Zhuo, "What drives consumer knowledge sharing in online travel communities?: Personal attributes or e-service factors?," Computers in Human Behavior, vol. 63, pp. 68-74, 2016.

[19] A. Bandura, "Self-Efficacy," in Encyclopedia of human behavior, New York, 1994.

[20] H. Wang, T. Wang, G. Yin and C. Yang, "Linking Issue Tracker with Q\&A Sites for Knowledge Sharing across Communities," IEEE Transactions on Services Computing, vol. 11, no. 5, pp. 782-795, 2015.

[21] A. Guimar aes, A. P. C. d. Silva and J. Almeida, "On the Dynamics of Topic-Based Communites in Online Knowledge-Sharing Networks," in 2015 Second European Network Intelligence Conference, Karlskrona, Sweden, 2015, 2015.

[22] H. Alali and J. Salim, "Virtual Communities of Practice Success Model to Support Knowledge Sharing behaviour in Healthcare Sector," Procedia Technology, vol. 11, pp. 176-183, 2013.

[23] R. Abdullah, S. Abdullah and M. Tee, "Web-based knowledge management model for managing and sharing green knowledge of software development in community of practice," in 2014 8th. Malaysian Software Engineering Conference (MySEC), Langkawi, Malaysia, 2014.

[24] L. Law and N. Fong, "Applying partial least squares structural equation modeling (PLS-SEM) in an investigation of undergraduate students' learning transfer of academic English," Journal of English for Academic Purposes, vol. 46, 2020.

[25] A. Leguina, "A primer on partial least squares structural equation modeling (PLS-SEM)," International Journal of Research \& Method in Education, vol. 38, no. 2, pp. 220-221, 2015.

[26] J. F. Hair, B. J. Babin, R. E. Anderson and W. C. Black, Multivariate Data Analysi, Cengage India, 2018.

[27] T. Raykov, "Estimation of Composite Reliability for Congeneric Measures," Applied Psychological Measurement, vol. 21, no. 2, 1997.

[28] S. R. Colwell, "The Composite Reliability Calculator User's Guide," 2016.

[29] G. Anuraga, E. Sulistiyawan and S. Munadhiroh, "Structural Equation Modeling - Partial Least Square untuk Pemodelan Indeks Pembangunan Kesehatan Masyarakat (IPKM) di Jawa Timur," in Seminar Nasional Matematika dan Aplikasinya, Surabaya, 2017.

[30] J. F. Hair, B. Black, B. J. Babin and R. E. Anderson, Multivariate Data Analysis, Pearson Education, 2010.

[31] R. Bevans, "An introduction to t-tests," Scribbr, 2020. [Online]. Available: https://www.scribbr.com/statistics/t-test/.

[32] M.-H. Hsu, T. L. Ju, C.-H. Yen and C.-M. Chang, "Knowledge sharing behavior in virtual communities: The relationship between trust, self-efficacy, and outcome expectations," International Journal of Human-Computer Studies, vol. 65, no. 2, 2007.

[33] L. J. Slikkerveer, "Gotong Royong: An Indigenous Institution of Communality and Mutual Assistance in Indonesia," in Integrated Community-Managed Development, Cham, 2019. 